\title{
THE COMPARISON OF ISLAMIC EDUCATION LEARNING OUTCOME WHICH WAS TREATMENT BY USING COOPERATIVE LEARNING MODEL OF STAD TYPE AND NHT TYPE AT STUDENTS CIASS X SMA PALOPO 3
}

\author{
Chandra Sangjaya ${ }^{1}$ \\ Muzakkir $^{2}$ \\ Muh. Rapi ${ }^{3}$ \\ Postgraduate Program of Alauddin State Islamic University Makassar, Indonesia ${ }^{1}$ \\ Faculty of Tarbiyah and Teacher Training UIN Alauddin Makassar, Indonesia ${ }^{2,3}$ \\ chandrasangjaya02@gmail.com ${ }^{1}, \underline{\text { muzakkir.ftk@uin-alauddin.ac.id }}^{2}, \underline{\text { mrapi@uin- }}$ \\ alauddin.ac.id ${ }^{3}$
}

\begin{abstract}
This research discussed about the comparison of learning outcomes in Islamic Education students who used the STAD type cooperative learning model and NHT type class X SMA Negeri 3 Palopo. This reasearch aimed to: 1) to determine the learning outcomes of Islamic Education students taught using the STAD type cooperative model in class $\mathrm{X}$ SMA Negeri 3 Palopo, 2) to know the Islamic Education learning outcomes of students taught using the NHT cooperative model on class X SMA Negeri 3 Palopo, 3) to Analyze the differences in Islamic Education learning outcomes of students taught by the STAD type cooperative model and student learning outcomes taught by the NHT cooperative model in Class X SMA Negeri 3 Palopo. This research was a quantitative research with a non-equivalent control group design. The population was all students of class X SMA Negeri 3 Palopo, totaling 260 students. The technique sampling was done by using purposive sampling. The instrument used was a test with descriptive statistical analysis and inferential analysis. Based on the analysis of descriptive data for the learning outcomes of students taught by using the STAD type cooperative learning model is very good category. The learning outcomes of students taught by using NHT type of cooperative learning model are very good category. Based on inferential analysis obtained a significant value $\alpha(0.7160 .05)$ then, it can be said that there is no significant difference between the learning outcomes of Islamic Religious Education taught using the STAD type cooperative learning model and those taught using the NHT learning model in Class students X SMA Negeri 3 Palopo.
\end{abstract}

Keywords: Learning Method; STAD; NHT

\section{INTRODUCTION}

Education is very important and fundamental for every individual both for personal interests and his position as a citizen. The success or failure for achieving educational goals depends on a lot how the learning process experienced by students. As an educator, it is known that a teacher's professionalism is not on his ability to develop knowledge, but rather on his ability to carry out an interesting learning meaningful for his students. 
In Fact, In learning process which was done by the teacher is mostly presented by using conventional models and a little questions and answers. It caused a students only receive information from the teachers and students are less required to actively and independently master the material. Most of them only expect help from the teacher without trying to cooperative with their friends. This situation can caused student learning outcomes achieved less than optimal.

Based on the observations of researchers at SMA Negeri 3 Palopo found that there were several problems, including the teachers do not use appropriate learning models and methods so that the students were less active and less enthusiastic in participating in learning. thus, students outcomes in learning process were not maximal, in the learning process especially in class, students are generally passive. They were rarely for answering questions which given by the teacher and the students' attention is lacking in learning process, because many students do other activities such as playing cellphones, turning to their friends and talking with other friends.

In accordance with the statement above, some of the learning outcomes of students were still low due to the lack of teachers in using the right approaches and methods. It made students less active and enthusiastic for participating in class therefore learning outcomes are not optimal. Especially at X IPA 2 and X IPA 5 of SMA Negeri 3 Palopo, teachers were dominant using the lecture method, thus there is no interaction between teachers and students. As a result, many students whose grades were below the standard minimum completeness criteria $(\mathrm{KKM})$, so that the learning outcomes were low.

This was in line with research which conducted by Heni Efriani, (2016) with the research title was the Effect of the Application of Cooperative Learning Models Student Team Achievement Division (STAD) type in Improving Student Learning Outcomes at Class X Islamic Education Subjects at SMK Muhammadiyah 1 Palembang.

The results of this research found that the application of using the STAD type cooperative learning model has a significant influence on student learning outcomes in Islamic Education subject at Class X with Islamic Da'wah Period Madinah material at SMK Muhamdiyah 1 Palembang.

That is why the researchers used the STAD type cooperative model and the NHT type cooperative model in Islamic Education lessons to improve student learning outcomes because both the learning model in applying the STAD type cooperative learning model and the application of the NHT type cooperative learning model can improve students learning outcomes and through this research hoped that the application of the STAD type cooperative learning model and the NHT type cooperative learning model can improve student learning outcomes, and can be proven that there were differences and comparison learning outcomes in Islamic Education subjects at class $\mathrm{X}$ SMA Negeri 3 Palopo by applying the STAD type cooperative learning model and the NHT type cooperative learning model. 


\section{THEORITICAL REVIEW}

\section{A. Understanding Cooperative Learning Models}

Cooperative learning comes from by the word cooperative which means to do things together by helping one another as a group or team. ${ }^{1}$

Cooperative learning models are guidelines or instructions for teaching strategies designed to achieve a learning goal. This guideline contains the responsibility of educators in planning, implementing, and evaluating learning activities. One of the goals in using the learning model is to increase the ability of students while learning. . ${ }^{2}$

Cooperative learning model is one of the learning models that were widely used to realize learning activities that are students centered (student oriented), especially to overcome problems in the learning process, including students who cannot cooperate with each other. ${ }^{3}$ Cooperative learning strives students to be able to teach something to other students. Teaching peers gave students an opportunity to learn something well at the same time. Students become interviewees for other students.

\section{B. Definition of STAD Cooperative Learning Model Type}

The STAD (Student Teams Achievement Divisions) cooperative learning model was developed by Slavin at John Hopkin University in the United States and the simplest cooperative learning model. The STAD cooperative learning model is a cooperative learning model where students are placed in a learning team consisting of 45 learners which is a mixture according to achievement level, gender, and ethnicity. ${ }^{4}$

The researcher concluded that the general description of the STAD type cooperative learning model was students which divided into groups that constisted four people with diverse abilities, genders, and tribes. Educators give a lesson and students in the group ensure that all members of the group can master the learning material, finally all students undergo an individual quiz about the material, and at that time they may not help each other. The values of the quiz results of each student are compared with their own average scores previously obtained, and the values are given prizes based on how high that value exceeds their previous score. Then These values were added together to get a group score, and groups who could reach certain criteria will get certificates or other prizes.

The steps in cooperative learning type Student Achievement divisions (STAD) consist of 6 phases; namely conveying goals and motivating students, conveying information, organizing students in study groups, evaluating and giving awards. The phases can be seen in the following table syntax 2.1 as follows.

\footnotetext{
${ }^{1}$ Isjoni, Cooperative Learning Mengembangkan Kemampuan Belajar Berkelompok (Cet. I; Bandung: Alfabeta 1997), h. 15.

${ }^{2}$ Trianto, Model-Model Pembelajaran Inovatif Berorientasi Konstruktifistik: Konsep, Landasan Teoretis Praktis dan Implementasinya (Jakarta: Prestasi Pustaka, 2007), h. 5.

${ }^{3}$ Isjoni, Cooperative Learning Mengembangkan Kemampuan Belajar Berkelompok, h. 18.

${ }^{4}$ Syahril Lukman, dkk., Pengeruh Model Pembelajaran Kooperatif Tipe Jigsaw dan STAD terhadap Hasil Belajar Geografi Ditinjau dari Motivasi Belajar Peserta Didik Kelas VIII SMP Negeri 1 Jatinom Klaten Tahun Pelajaran 2013/2014, h. 3.
} 
Tabel Syntax Cooperative Learning Model STAD Type

\begin{tabular}{|c|c|}
\hline Phase & Teacher Activities \\
\hline $\begin{array}{c}\text { Phase } 1 \\
\text { Delivering goals and } \\
\text { motivating students }\end{array}$ & $\begin{array}{l}\text { Delivering all the learning objectives to be achieved } \\
\text { in these lessons and motivate students to learn }\end{array}$ \\
\hline $\begin{array}{c}\text { Phase } 2 \\
\text { Presenting information }\end{array}$ & $\begin{array}{l}\text { The teacher presents information to students by } \\
\text { means of demonstrations or through reading material }\end{array}$ \\
\hline $\begin{array}{c}\text { Phase } 3 \\
\text { Organize students in } \\
\text { study groups }\end{array}$ & $\begin{array}{l}\text { Explaining to students how to form study groups and } \\
\text { how to help each group make the transition } \\
\text { efficiently }\end{array}$ \\
\hline $\begin{array}{l}\text { Phase } 4 \\
\text { Guiding work group and } \\
\text { study groups }\end{array}$ & Guiding study groups as they do their work \\
\hline $\begin{array}{l}\text { Phase } 5 \\
\text { Evaluation }\end{array}$ & $\begin{array}{l}\text { Evaluating the results of learning about the material } \\
\text { that has been taught or each group presents their wo }\end{array}$ \\
\hline $\begin{array}{c}\text { Phase } 6 \\
\text { Giving rewards }\end{array}$ & $\begin{array}{l}\text { Look for ways to appreciate the efforts and learning } \\
\text { outcomes of individuals and group }\end{array}$ \\
\hline
\end{tabular}

Source: Trianto, 2007.

\section{Definition of NHT Cooperative Learning Model}

Numbered Head Together was a variance from the technical group discussion where the implementation is almost the same as the group discussion. Firstly, the teacher asked students to sit in groups. Each member was given a number. After finishing, the teacher called the number (read; member) to present the results of the discussion. The teacher does not tell the number what will be the next presentation. And so on until all numbers are called. randomly calling will ensure that all students were really involved in the discussion. According to Slavin, the method developed by Russ Frank is suitable for ensuring individual accountability in group discussions. 5

Numbered Head Together teaching and learning technique (Numbered Head Together) is one of the approaches developed by Spencer Kagan, to involve more students in studying the material which was included in a learning as well as checking their understanding of the learning content.

Numbered Head Together learning model is a way of cooperative learning or several groups in which children were grouped into groups, each student in each group gets a number, the teacher assigned tasks to each student based on numbers. Thus, each student has a different task. The Numbered Head Together learning model was also a way of presenting lessons by experimenting, experiencing and proving itself the problem being learned. With the Numbered Head Together model, students were given the opportunity to experience themselves, do it themselves, follow the process, observe

\footnotetext{
${ }^{5}$ Huda Miftahul, Cooperative Learning (Yogyakarta: Pustaka Pelajar, 2011), h. 130.
} 
an object, analyze the evidence, and draw their own conclusions about an object and the state of a particular subject learning process. ${ }^{6}$

The Numbered Head Together (NHT) Type of Cooperative Learning Model has four stages in its implementation as follows:

\section{Syntax Table NHT Type Cooperative Learning Model NHT Type}

\begin{tabular}{cl}
\hline Implementation Stage & \multicolumn{1}{c}{ Teacher's Activity } \\
\hline $\begin{array}{c}\text { Stage 1 } \\
\text { Numbering }\end{array}$ & $\begin{array}{l}\text { The teacher divided students into groups of 3-5 people } \\
\text { and each group member was given a number so that } \\
\text { each student in the team has a number that varies } \\
\text { according to the number of students in the group }\end{array}$ \\
\hline $\begin{array}{c}\text { Stage 2 } \\
\text { Asking question }\end{array}$ & $\begin{array}{l}\text { The teacher asked a question to students. The questions } \\
\text { given can be taken from certain subject matter which is } \\
\text { indeed being studied, in making the questions try to vary } \\
\text { from specific levels to be general with varying degrees } \\
\text { of difficulty as well }\end{array}$ \\
\hline Stage 3 & $\begin{array}{l}\text { After getting questions from the teacher, students think } \\
\text { together to unite opinions on the answers to these } \\
\text { questions and convince each member in his team to } \\
\text { know the answers }\end{array}$ \\
\hline Stage 4 & $\begin{array}{l}\text { The teacher called a number, then learners whose } \\
\text { numbers were appropriate raise their hands and tried to } \\
\text { answer questions for the whole class. On calling a }\end{array}$ \\
& number, the teacher randomly called the numbers 1 to x \\
(x is the number of students in the group). Children \\
selected in stage 4 are children who are expected to \\
answer.
\end{tabular}

\section{Definition of Learning Outcomes}

Learning is a change in behavior, where the change can lead to better behavior but there is also the possibility of leading to bad behavior. ${ }^{7}$

Learning outcomes were the realization or expansion of potential skills or capacities owned by someone. The mastery of learning outcomes by someone can be seen from their behavior, both behavior in the form of mastery of knowledge, thinking skills and motor skills. Actually, almost all developments or advancements attainments were also learning outcomes, because the learning process does not only take place at school but also at working place and in the community. ${ }^{8}$

From the description above, the writer draws the conclusion that learning outcomes are the results achieved by a student after following the learning process within a certain period of time obtained from the measurement results through a measuring instrument in the form of learning outcomes tests.

\footnotetext{
${ }^{6}$ Huda Miftahul, Cooperative Learning (Yogyakarta: Pustaka Pelajar, 2011), h. 130.

${ }^{7}$ M. Ngalim Purwanto, Psikologi Pendidikan (Bandung: Remaja Rosdakarya, 2007), h. 85.

${ }^{8}$ Nana Syaodih Sukmadinata, Landasan Psikologi Proses Pendidikan (Bandung: Remaja Rosdakarya, 2005), h. 102.
} 


\section{III.RESEARCH METHODOLOGY}

This research was a quantitative desingn with a non-equivalent control group design. The population was all students of class X SMA Negeri 3 Palopo, totaling 260 people. The sample selection technique was done by using purposive sampling. The instrument used was a test with descriptive statistical analysis and inferential analysis.

\section{IV.RESULT AND DISCUSSION}

\section{A. Islamic Education Learning Outcomes Grade X Students of SMA Negeri 3 Palopo taught by the Student Teams Achievement Divisions Learning Model}

Based on the results of descriptive statistical analysis before being given treatment, the results of the average pretest value for experimental class I that is equal to 46.80 there are 1 students $(4.00 \%)$ were very less, 9 students $(36.00 \%)$ were poor category, 13 students $(52.00 \%)$ were rather good, 2 students $(08.00 \%)$ were good category while very good category there were no students $(0 \%)$ in that category. therefore, it can be concluded that the learning outcomes of Islamic Education after being interpreted are still very unsatisfactory because there are $36.00 \%$ of students who are in lacking category.

After the experimental class I was treated with the STAD type cooperative learning model then given the results of the test there were no students in the very poor, less and sufficient categories, while good category there were 7 students $(28.00 \%)$ and 18 students $(72,00 \%)$ was very good category. Therefore it can be concluded that the Islamic Religious Education learning outcomes after the posttest is found $(72.00 \%)$ were very good category, with an average value of 87.20 means an increase in learning outcomes.

The results of this research were in line with research conducted by Heni Efriani, with the title "The Effect of the Application of Cooperative Learning Models Type Student Team Achievement Division (STAD) in Improving Student Learning Outcomes in Subjects of Islamic Education Class X in SMK Muhammadiyah 1 Palembang". The results showed that the application without using the STAD type cooperative learning model and using the STAD type cooperative learning model was classified as moderate and by using the STAD type cooperative learning model there was an increase. The application using the STAD type cooperative learning model has a significant effect on the learning outcomes of students in the subject of Islamic Religious Education class $\mathrm{X}$ Islamic Madwah Period Islamic material at SMK Muhammadiyah 1 Palembang. ${ }^{9}$

\section{B. Islamic Education Learning Outcomes Students in Class at X SMA Negeri 3 Palopo taught by the Learning Model Numbered Head Together}

Based on the results of descriptive statistical analysis before being given treatment, the results of the average pretest value for experimental class II results of descriptive statistical analysis before being given treatment, the average value of 46.20 ,

\footnotetext{
${ }^{9}$ Heni Efriani, "Pengaruh Penerapan Model Pembelajaran Kooperatif Tipe Student Team Achiement Division (STAD) dalam Meningkatkan Hasil Belajar Peserta Didik pada Mata Pelajaran Pendidikan Agama Islam Kelas X Di SMK Muhammadiyah 1 Palembang", Tesis (Palembang: Universitas Islam Negeri Raden Fatah, 2016)
} 
there were 15 students $(60.00 \%)$ were less category , 10 students were in the sufficient category, whereas in the good and very good category there were no students $(0 \%)$ in that category. Therefore it can be concluded that the learning outcomes of Islamic Religious Education after the pretest is still very unsatisfactory because it is clear there are $60.00 \%$ of students who are less category.

In the experimental class II were treated with the NHT type of cooperative learning model then given the results of the test there were no students in the category of very less, less and enough, while in the good category there were 6 students $(24.00 \%)$ and 19 students $(76,00 \%)$ were very good category. Therefore it can be concluded that the Islamic Religious Education learning outcomes after the posttest is found $(76.00 \%)$ very good category with an average value of 87.80 which means an increase in learning outcomes.

The results of this research were in line with research conducted by Sitti Nurfitriyani Kusumawat, with the research title "Implementation of the Numbered Head Together (NHT) Method in Improving Student Learning Outcomes in Islamic Religious Education Subjects in Muhammadiyah 5 Pucang Middle School". The final results of this research PAI learning with the Numbered Heads Together (NHT) model is appropriate and appropriate. There is an increase in learning outcomes or grades before and after treatment. There are differences in learning outcomes of students taught using the Numbered Head Together (NHT) Method, with student learning outcomes using the Conventional method. ${ }^{10}$

\section{Significance Difference between Islamic Education Learning Outcomes Students taught by using Cooperative Model Type Student Achievement Divisions and Islamic Education Learning Outcomes taught by the Cooperative Model Numbered Head Together Type in Class at X Students of SMA Negeri 3 Palopo.}

In this analysis there are 3 stages to find out whether there are significant differences in the application of the two learning models to the learning outcomes of Islamic Religious Education students. The intended stage is normality testing, then homogeneity testing is done and the last stage is hypothesis testing with $\mathrm{t}$-test.

In testing the hypothesis, the data were first tested for normality and homogeneity using SPSS version 26. The pretest results of the experimental class I obtained sig $>\alpha(0.052>0.05)$ and in experimental class II the value of $\operatorname{sig}>\alpha(0.052>$ $0.05)$. The experimental class I posttest results obtained sig $>\alpha(0.051>0.05)$, and the experimental class II obtained sig $>\alpha(0.051>0.05)$, so it can be concluded that the data are normally distributed.

Homogeneity test on the pretest results obtained sig $>\alpha(0.958>0.05)$, at the postest obtained sig $>\alpha(1,000>0.05)$, so it can be concluded that both homogeneous data. When testing with the t-test statistic the test used is independent sample test data in the Equal Variances assumed column, the value of sig $=0.716$ is obtained because sig $>\alpha$ is $0.0716>0.05$ thus $\mathrm{H} 0$ is accepted $\mathrm{H} 1$ is rejected.

Thus the hypothesis proposed is tested by the data, Thus it can be concluded that there is no significant difference between the learning outcomes of Islamic Education

\footnotetext{
${ }^{10}$ Sitti Nurfitriyani Kusumawati, "Implementasi metode Numbered Head Together (NHT) dalam meningkatkan hasil belajar peserta didik pada mata pelajaran Pendidikan Agama Islam di SMP Muhamdiyah 5 Pucang Surabaya", Tesis (Surabaya: UIN Sunan Ampel, 2014).
} 
grade $\mathrm{X}$ students of SMA Negeri 3 Palopo who are taught using the STAD type cooperative learning model and those taught using the NHT type cooperative learning model.

The results of this research are also in line with research conducted by Nita Indriastuti with the title, "Comparative Study of Student Teams Achievement Division (STAD) and Numbered Heads Together (NHT) Strategies for Mathematics Learning Results for Class IV SDN 1 Students in Dipuran Boyolali Students". The results showed (1) there was no significant difference in the influence of STAD and NHT strategies on mathematics learning outcomes of grade IV students of SDN 1 Dipuran Boyolali students; (2) The STAD and NHT strategies have the same effect in mathematics learning, especially the material units of time, although the average value generated through the application of the two strategies has a slight difference. ${ }^{11}$

Some factors caused that there was no difference between the cooperative learning model of the STAD type and the NHT type are follows :

1. Because both models were cooperative learning models that are both simple and easy to apply.

2. The application of the two models is the same that distinguishes only the final step, namely the giving of scores and team awards.

3. Because when implementing learning the treatment was the same as the prerequisite test results, concluding that all samples come from normally distributed.

\section{CONCLUSION}

Based on the description and discussion, then in this case the researcher can be drawn the following conclusions:

Islamic Education learning outcomes taught by using the NHT type of cooperative learning model in class at X IPA 5 SMA Negeri 3 Palopo, there were no students in the category of very less, less and enough, while in the good category there are 6 students $(24.00 \%)$ and 19 students $(76.00 \%)$ were in the very good category. Therefore it can be concluded that the Islamic Education learning outcomes after the posttest is found $(76.00 \%)$ in the very good category with an average value of 87.80 which means an increase in learning outcomes.

There is no significant difference between Islamic Education learning outcomes of class X students of SMA Negeri 3 Palopo who are taught using the STAD type cooperative learning model and those taught using the NHT type cooperative learning model.

\footnotetext{
${ }^{11}$ Nita Indriastuti, “Studi Komparasi Strategi Student Teams Achievement Division (STAD) dan Numbered Heads Together (NHT) terhadap Hasil Belajar Matematika Peserta didik Kelas IV SDN 1 Siswa Dipuran Boyolali", Tesis (Surakarta: Program Pascasarjana Universitas Muslim Muhamadiyah Makassar, 2015).
} 
The Comparison of Islamic Education Learning Outcome Which Was Treatment by Using Cooperative Learning Model of Stad Type and NHT Type at Students Class X SMA Palopo 3 REFERENCE

Heni, Efriani. "Pengaruh Penerapan Model Pembelajaran Kooperatif Tipe Student Team Achiement Division (STAD) dalam Meningkatkan Hasil Belajar Peserta Didik pada Mata Pelajaran Pendidikan Agama Islam kelas X Di SMK Muhammadiyah 1 Palembang". Tesis. Palembang: Universitas Islam Negeri Raden Fatah, 2016.

Kusumawati, Sitti Nurfitriyani. "Implementasi metode Numbered Head Together (NHT) dalam meningkatkan hasil belajar peserta didik pada mata pelajaran Pendidikan Agama Islam di SMP Muhamdiyah 5 Pucang Surabaya”. Tesis. Surabaya: UIN Sunan Ampel, 2014.

Lukman, Syahril, dkk. "Pengeruh Model Pembelajaran Kooperatif Tipe Jigsaw dan STAD Terhadap Hasil Belajar Geografi Ditinjau dari Motivasi Belajar Peserta didik Kelas VIII SMP Nenegi 1 Jatinom Klaten Tahun Pelajaran 2013/2014.

Miftahul, Huda. Cooperative Learning. Yogyakarta: Pustaka Pelajar. 2011.

Purwanto, M., Ngalim. Psikologi Pendidikan. Bandung: Remaja Rosdakarya, 2007.

Sukmadinata, Nana Syaodih. Landasan Psikologi Proses Pendidikan. Bandung: Remaja Rosdakarya, 2005.

Ibrahim, Muslim dkk. Pembelajaran Kooperatif. Surabaya: Unversity Pers, 2000.

Indriastuti, Nita. Studi Komparasi Strategi Student Teams Achievement Division (STAD) dan Numbered Heads Together (NHT) terhadap Hasil Belajar Matematika Peserta Didik Kelas IV SDN 1 Siswa Dipuran Boyolali. Tesis. Surakarta: Program Pascasarjana Universitas Muslim Muhamadiyah Makassar, 2015.

Isjoni, Cooperative Learning Mengembangkan Kemampuan Belajar Berkelompok. Bandung: Alfabeta, 1997.

Trianto. Model-Model Pembelajaran Inovatif Berorientasi Konstruktifistik: Konsep, Landasan Teoretis Praktis dan Implementasinya. Jakarta: Prestasi Pustaka, 2007. 